\title{
The Relationship Between Iron Accumulation, Vitamin D Deficiency and Bone Mineral Density in Patients with Thalassemia Major, Thalassemia Intermedia and Sickle Cell
}

\author{
Talasemi Majör, Intermedya ve Orak Hücreli Hastalarda Demir Birikimi ve D Vitamini \\ Eksikliği ile Kemik Mineral Yoğunluğu ilişskisi
}

\author{
(D) Mahmut Büyükşimşek, (D) Ismail Fikri Başlamışlı* \\ Çukurova University Faculty of Medicine, Department of Medical Oncology, Adana, Turkey \\ *Çukurova University Faculty of Medicine, Department of Hematology, Adana, Turkey
}

\section{Abstract}

Objective: Osteopenia and osteoporosis are important causes of morbidity in patients with hemoglobinopathies. This study investigates the association between iron accumulation, vitamin $\mathrm{D}$ and bone mineral density (BMD) in patients with thalassemia major, thalassemia intermedia and sickle cell.

Materials and Methods: Serum samples collected from 102 patients with hemoglobinopathy were used; the relationship between ferritin, vitamin D levels and BMD, which was performed with dual energy X-ray absorptiometry (DEXA), was investigated.

Results: The ratio of thalassemia intermedia, thalassemia major and sickle cell patients with normal BMD according to the DEXA Femoral T-score was $56.25 \%, 35 \%$ and 39\%, respectively. The ratio of thalassemia intermedia, thalassemia major and sickle cell patients with normal BMD according to the DEXA lumbar T-score was 31.25\%, 7.5\% and $41.25 \%$, respectively. When the patients' ferritin values and DEXA scores were compared, femur T-score, lumbar T-score, femur Z-score and lumbar Z-score were significantly lower in those with high ferritin values ( $p$ values were respectively: $0.0005,0.0002,<0.0001,0.0002$ ). When the femur T-score, lumbar T-score, femur Z-score and lumbar Z-score were compared in patients with normal and low vitamin D levels, a statistically significant change was observed in the severe deficiency patients ( $p$ values were respectively: $0.001,0.001,0.0027,0.0003$ ).

Conclusion: Patients with hemoglobinopathy should be screened through DEXA at an early age. The efforts to provide appropriate vitamin $\mathrm{D}$ replacement and to restore the ferritin levels to the normal range may be effective in reducing the morbidity associated with osteoporosis. Keywords: Hemoglobinopathies, osteoporosis, iron accumulation, vitamin D

\section{Öz}

Amaç: Osteopeni ve osteoporoz hemoglobinopatili hastalarda önemli bir morbidite nedenidir. Bu çalışmanın amacı talasemi majör, talasemi intermedya ve orak hücreli anemi hastalarında demir birikimi, D vitamini ve kemik mineral yoğunluğu (KMY) arasındaki ilişkiyi araştırmaktır. Gereç ve Yöntem: Hemoglobinopatili 102 hastadan serum örnekleri toplandı ve ferritin ve D vitamini düzeyleri ile çift enerjili X-ş̧ını absorpsiyometrisiyle (DEXA) ölçülen KMY arasındaki ilişki araştııılı.

Bulgular: DEXA femoral T-skoruna göre normal KMY olan talasemi intermedya, talasemi majör ve orak hücreli anemi hasta oranı sırasıyla \%56,25, \%35 ve \%39 idi. DEXA lomber T-skoruna göre normal KMY olan talasemi intermedya, talasemi majör ve orak hücreli anemi hasta oranı sırasıyla \%31,25, \%7,5 ve \%41,25 idi. Hastaların ferritin değerleri ve DEXA skorları karşılaştıııldı̆ında, femur T-skoru, lomber T-skoru, femur Z-skoru ve lomber Z-skoru, ferritin değeri yüksek olanlarda istatistiksel olarak anlamlı derecede düşüktü ( $p$ değerleri sırasıyla: 0,0005, 0,0002, <0,0001, 0,0002). Femur T-skoru, lomber T-skoru, femur Z-skoru ve lomber Z-skoru normal ve düşük D vitamini seviyesine sahip hastalarda karşılaştııılığında, ciddi eksikliği olan hastalarda istatistiksel olarak anlamlı bir değişiklik gözlendi ( $p$ değerleri sırasıyla: 0,001, 0,001, 0,0027, 0,0003).

Sonuç: Hemoglobinopatili hastalar DEXA ile erken yaşta taranmalıdır. Uygun D vitamini replasmanının sağlanması ve ferritin seviyelerinin normal aralığa getirilmesi çabaları osteoporoz ile ilişkili morbiditeyi azaltmada etkili olabilir.

Anahtar kelimeler: Hemoglobinopatiler, osteoporoz, demir birikimi, vitamin D

Address for Correspondence/Yazışma Adresi: Mahmut Büyükşimşek MD, Çukurova University Faculty of Medicine, Department of Medical Oncology Adana, Turkey Phone: +90 5368622026 E-mail: mahmutbuyuksimsek@gmail.com ORCID ID: orcid.org/0000-0001-6356-9059 Received/Geliş Tarihi: 04.12.2019 Accepted/Kabul Tarihi: 15.01.2020

${ }^{\circ}$ Copyright 2020 by the Turkish Osteoporosis Society / Turkish Journal of Osteoporosis published by Galenos Publishing House 


\section{Introduction}

Osteopenia and osteoporosis is an important cause of morbidity in patients with hemoglobinopathy across all genders and ages. Many genetic and acquired factors are inculpated for the pathogenesis of osteoporosis in these patients. Some of the acquired factors for osteoporosis in these patients include thinning of cortical and trabecular bone due to bone marrow expansion caused by increased ineffective erythropoiesis, calcium and phosphorus metabolism disorders, hypogonadotropic hypogonadism, growth hormone and IGF-1 deficiency, delayed puberty, increased osteoclast activity and decreased osteoblast activity, toxic effect of desferrioxamine chelation treatment and physical inactivity (1-4). In recent years, developments in transfusion management and chelation treatment improved the skeletal development and cosmetic bone appearance. However, these patients are still reported to have low bone density despite the optimal conventional treatment and reduction of endocrinal complications (5). Vitamin D is a basic hormone for the control of normal calcium and phosphate homeostasis, and also an important factor required for bone development and the continuity of bone mass (6). Elevated serum ferritin level points to iron storage in the organs including bones especially in patients with transfusion-dependent thalassemia major. Excessive iron deposition in bones impairs the number and activation of osteoid and bone mineralization, leading to osteoporosis (7). In our region, thalassemia major, intermedia and sickle cell disease are quite common and for these patient groups, osteoporosis causes frequent morbidity in early ages. In this study we wanted to investigate the association between the iron accumulation, vitamin $\mathrm{D}$ and bone mineral density (BMD) in thalassemia major, intermedia and sickle cell patients.

\section{Materials and Methods}

In this cross-sectional observational study, the approval of the Çukurova University Faculty of Medicine of Local Ethics Committee (decision no: 2014/27) was obtained and 102 patients with thalassemia major, intermedia and sickle cell who admitted to Çukurova University Hematology Outpatient Clinic from 2013 to 2015 were analyzed. Written consent form was obtained from all patients before enrollment in the study. The patients were divided into three groups: patients with thalassemia intermedia, thalassemia major and sickle cell. Patients who received regular transfusion and chelation therapy were included in the study. The patients who did not receive osteoporosis treatment before, did not use any medication that could affect the calcium and vitamin D metabolism (anticonvulsants, gonadotropin releasing hormone analogues, cyclosporine, estrogen preparations, calcium and vitamin D-containing medications), did not have any known renal or hepatic disease, did not have any known metabolic bone disease, did not have any health problem except hemoglobinopathy that might lead to secondary osteoporosis (hyperthyroidism, use of steroid etc) were included in the study. Therefore, 50 patients were excluded from the study for these reasons. Fasting blood test was performed for the eligible patients included in the study and their dual energy X-ray absorptiometry (DEXA) measurements were performed. Ferritin and vitamin D levels were examined in the blood sample. Serum vitamin D levels were measured using a Chromosystem test kit (Chromosystem, Munich, Germany) using high performance liquid chromatography method. Ferritin was measured by electro chemiluminescence method, by using BIO Diagnostic Products Corporation (DPC), Los Angeles, USA test kit and by ImmuliteONE instrument. The DEXA method was used for the diagnosis of osteoporosis. The BMD of the patients was measured on anterio-posterior and lateral lumbar vertebrae (L1L4) and left femur neck. Fractured sites or prosthetic sites were not measured. The measurements were performed with DEXA (Norland, XR 46, USA) at radiology department. Measurements were completed in as short as 7-20 minutes, depending on the region where the shots were taken, and BMD results were expressed in $\mathrm{g} / \mathrm{cm}^{2}$, as T- and Z-score. T- and Z-scores were used in evaluating DEXA results. T-score is the standard deviation (SD) of BMD according to a person's young age group. The Z-score is the SD of BMD according to the individual's age group, used in the diagnosis of secondary osteoporosis. We evaluated both T- and Z-scores for our patient groups. The results of the BMD were divided into 3 groups as osteoporosis, osteopenia and normal according to T-score in line with the criteria proposed by the World Health Organization. Patients with a vertebral and/ or femoral T-score of $\leq-2.5$ were assigned to the osteoporosis group, those with a T-score of $-2.5<$ to $\leq-1.0$ were assigned to the osteopenia group, and those with a T-score of >-1.0 were assigned to the normal group. The patients' Z-scores were also evaluated. Those patients with a Z-score of -2 SD and below were considered to have a lower bone mass than expected based on their chronological age, while those with a Z-score above -2 SD considered to have a normal bone mass according to their chronological age.

\section{Biochemical Analysis}

The normal range was considered as 23.9-336.2 $\mathrm{ng} / \mathrm{mL}$ for ferritin. The normal range of vitamin D was taken as 30-120 ng/ $\mathrm{mL}$. 20-29.9 ng/mL was considered as mild vitamin D deficiency, 10-19.9 ng/mL was considered as medium vitamin D deficiency, and a value lower than $10 \mathrm{ng} / \mathrm{mL}$ was considered as severe vitamin $\mathrm{D}$ deficiency.

\section{Statistical Analysis}

The statistical analysis of the data was performed using Microsoft Windows compatible SPSS 21.0 package software. The descriptive statistics were expressed as numbers and percentage (\%) for categorical variables, and as means and SD (and as median and minimum-maximum when required) for continuous variables. For the comparison of continuous variables between the groups, the distribution was analyzed. One-Way ANOVA test was performed for the parameters with a normal distribution depending on the number of variables One-Way. For the comparison of the categorical variables, chi-square test was 
used. The effects of ferritin and vitamin D levels on BMD were compared using cox multi regression analysis. $P$ value of 0.05 was considered to be statistically significant in all tests.

\section{Results}

Sixteen patients had thalassemia intermedia (15.7\%), 40 had thalassemia major (39.2\%), 46 had sickle cell disease (45.1\%). Demographic and laboratory data of patients are presented in Table 1. Patients with thalassemia intermedia were diagnosed at a mean age of 8 years and the mean follow-up was 19 years; patients with thalassemia major were diagnosed at a mean age of 1 year and the mean follow-up was 24 years; patients with sickle cell disease were diagnosed at a mean age of 6 years and the mean follow-up was 22 years. In patients with thalassemia intermedia and major, lomber T- and Z-scores were significantly lower than femur $T$ - and Z-scores $(p=0.028, p=0.015, p=0.035$, $p=0.03$ respectively). There was no statistically difference between lumbar and femur regions in sickle cell patients $(p=0.87, p=0.9$ ). The classification of the patients according to their ferritin levels is indicated in Table 2. The classification of the patients according to their vitamin D levels is shown in Table 3. The mean vitamin $D$ levels, in the group of very high ferritin levels $(>=1.000 \mathrm{ng} / \mathrm{mL}$ ) and in the group of whose ferritin levels $<1.000 \mathrm{ng} / \mathrm{mL}$, were 13.7 and 14.8 , respectively and this was not statistically significant $(p=0.08$ ). The ratio of patients with thalassemia intermedia, thalassemia major and sickle cell with normal BMD according to DEXA femoral T-score was $56.25 \%, 35 \%$ and $39 \%$, respectively. The ratio of patients with thalassemia intermedia, thalassemia major and sickle cell with normal BMD according to DEXA lumbar T-score was 31.25\%,

Table 1. Demographic and laboratory data of patients

\begin{tabular}{|c|c|c|c|}
\hline Parameter & $\begin{array}{l}\text { Thalassemia } \\
\text { intermedia } \\
\text { mean } \pm \text { SD } \\
(n=16)\end{array}$ & $\begin{array}{l}\text { Thalassemia } \\
\text { major } \\
\text { mean } \pm \text { SD } \\
(n=40)\end{array}$ & $\begin{array}{l}\text { Sickle cell } \\
\text { patients } \\
\text { mean } \pm \text { SD } \\
(n=46)\end{array}$ \\
\hline Mean age & $29 \pm 11$ & $25 \pm 7$ & $31 \pm 10$ \\
\hline \multicolumn{4}{|l|}{ Gender } \\
\hline $\begin{array}{l}\text { Female } \\
\text { Male }\end{array}$ & $\begin{array}{l}9 \\
7\end{array}$ & $\begin{array}{l}18 \\
22\end{array}$ & $\begin{array}{l}23 \\
23\end{array}$ \\
\hline Ferritin & $\begin{array}{l}782.08 \pm 880.39 \\
\mathrm{ng} / \mathrm{mL}\end{array}$ & $\begin{array}{l}1386.75 \pm 1264.94 \\
\mathrm{ng} / \mathrm{mL}\end{array}$ & $\begin{array}{l}921.05 \pm 996.62 \\
\mathrm{ng} / \mathrm{mL}\end{array}$ \\
\hline Vitamin D & $\begin{array}{l}17.87 \pm 10.09 \\
\mathrm{ng} / \mathrm{mL}\end{array}$ & $\begin{array}{l}15.70 \pm 11.19 \\
\mathrm{ng} / \mathrm{mL}\end{array}$ & $\begin{array}{l}15.84 \pm 10.98 \\
\mathrm{ng} / \mathrm{mL}\end{array}$ \\
\hline $\begin{array}{l}\text { Femoral } \\
\text { T-score }\end{array}$ & $-0.97 \pm 1.33$ & $-1.41 \pm 1.05$ & $-0.88 \pm 1.98$ \\
\hline $\begin{array}{l}\text { Lumbar } \\
\text { T-score }\end{array}$ & $\begin{array}{l}-1.89 \pm 1.61 \\
p=0.028\end{array}$ & $\begin{array}{l}-2.36 \pm 1.07 \\
p=0.035\end{array}$ & $\begin{array}{l}-0.80 \pm 2.31 \\
p=0.87\end{array}$ \\
\hline $\begin{array}{l}\text { Femoral } \\
\text { Z-score }\end{array}$ & $-0.5 \pm 1.43$ & $-1.39 \pm 1.05$ & $-0.73 \pm 2.02$ \\
\hline $\begin{array}{l}\text { Lumbar } \\
\text { Z-score }\end{array}$ & $\begin{array}{l}-1.42 \pm 1.57 \\
p=0.015\end{array}$ & $\begin{array}{l}-2.31 \pm 1.08 \\
p=0.03\end{array}$ & $\begin{array}{l}-0.58 \pm 2.29 \\
p=0.9\end{array}$ \\
\hline \multicolumn{4}{|c|}{ SD: Standard deviation } \\
\hline
\end{tabular}

$7.5 \%$ and $41.25 \%$, respectively. Table 4 presents the comparison between the vitamin D levels and BMD of all patients. When the femur- T-score, lomber T-score, femur Z-score and lomber Z-score were compared in patients with normal and low Table 2. Classification of the patients based on their ferritin levels

\begin{tabular}{|l|l|l|l|}
\hline \multirow{2}{*}{} & \multicolumn{3}{|c|}{ Ferritin } \\
\cline { 2 - 4 } & Low & Normal & High \\
\hline $\begin{array}{l}\text { Thalassemia } \\
\text { intermedia } \\
\text { (n=16) }\end{array}$ & $1(6.2 \%)$ & $2(12.5 \%)$ & $13(81.2 \%)$ \\
\hline $\begin{array}{l}\text { Thalassemia major } \\
\text { (n=40) }\end{array}$ & $0(0 \%)$ & $2(5 \%)$ & $38(95 \%)$ \\
\hline $\begin{array}{l}\text { Sickle cell patients } \\
\text { (n=46) }\end{array}$ & $1(2.2 \%)$ & $18(39.1 \%)$ & $27(58.7 \%)$ \\
\hline Low: $\leq 23.9 \mathrm{ng} / \mathrm{mL}$, Normal: $23.9-336.2 \mathrm{ng} / \mathrm{mL}$ High: $\geq 336.2 \mathrm{ng} / \mathrm{mL}$ \\
\hline
\end{tabular}

Table 3. Classification of the patients based on their vitamin D levels

\begin{tabular}{|l|l|l|l|l|}
\hline & \multicolumn{4}{|c|}{ Vitamin D } \\
\cline { 2 - 5 } & $\begin{array}{l}\text { Mild } \\
\text { deficiency }\end{array}$ & $\begin{array}{l}\text { Medium } \\
\text { deficiency }\end{array}$ & $\begin{array}{l}\text { Severe } \\
\text { deficiency }\end{array}$ & Normal \\
\hline $\begin{array}{l}\text { Thalassemia } \\
\text { intermedia } \\
\text { (n=16) }\end{array}$ & $4(25 \%)$ & $4(25 \%)$ & $4(25 \%)$ & $4(25 \%)$ \\
\hline $\begin{array}{l}\text { Thalassemia } \\
\text { major } \\
\text { (n=40) }\end{array}$ & $5(12.5 \%)$ & $19(47.5 \%)$ & $12(30 \%)$ & $4(10 \%)$ \\
\hline $\begin{array}{l}\text { Sickle cell } \\
\text { patie nts } \\
\text { (n=46) }\end{array}$ & $3(6.5 \%)$ & $20(43.5 \%)$ & $16(34.8 \%)$ & $7(15.2 \%)$ \\
\hline $\begin{array}{l}\text { Mild deficiency: } 20-29.9 \mathrm{ng} / \mathrm{mL}, \text { Medium deficiency: } 10-19.9 \mathrm{ng} / \mathrm{mL}, \text { Severe } \\
\text { deficiency: <10 ng/mL, Normal: } 30-120 \mathrm{ng} / \mathrm{mL}\end{array}$ \\
\hline
\end{tabular}

Table 4. Comparison between vitamin D levels and bone mineral densitometry of all patients

\begin{tabular}{|l|l|l|l|l|}
\hline Vitamin D & $\begin{array}{l}\text { DEXA } \\
\text { femoral } \\
\text { T-score } \\
\text { mean } \pm \\
\text { SD }\end{array}$ & $\begin{array}{l}\text { DEXA } \\
\text { lumbar } \\
\text { T-score } \\
\text { mean } \pm \\
\text { SD }\end{array}$ & $\begin{array}{l}\text { DEXA } \\
\text { femoral } \\
\text { Z-score } \\
\text { mean } \pm \\
\text { SD }\end{array}$ & $\begin{array}{l}\text { DEXA } \\
\text { lumbar } \\
\text { Z-score } \\
\text { mean } \pm \\
\text { SD }\end{array}$ \\
\hline $\begin{array}{l}\text { Severe } \\
\text { deficiency } \\
\text { (n=32) }\end{array}$ & $\begin{array}{l}-1.82 \pm 0.88 \\
p=0.001\end{array}$ & $\begin{array}{l}-2.5 \pm 0.94 \\
p=0.001\end{array}$ & $\begin{array}{l}-1.66 \pm 1.0 \\
p=0.0027\end{array}$ & $\begin{array}{l}-2.23 \pm 1.02 \\
p=0.0003\end{array}$ \\
\hline $\begin{array}{l}\text { Medium } \\
\text { deficiency } \\
\text { (n=43) }\end{array}$ & $-0.84 \pm 1.88$ & $-1.26 \pm 2.21$ & $-0.73 \pm 1.92$ & $-1.14 \pm 2.3$ \\
$p=0.66$ & $p=0.42$ & $p=0.62$ & $p=0.37$ \\
\hline $\begin{array}{l}\text { Mild } \\
\text { deficiency } \\
\text { (n=12) }\end{array}$ & $-0.76 \pm 1.39$ & $-1.35 \pm 2.14$ & $-0.52 \pm 1.5$ & $-1.05 \pm 1.98$ \\
$p=0.78$ & $p=0.44$ & $p=0.92$ & $p=0.53$ \\
\hline $\begin{array}{l}\text { Normal } \\
\text { (n=15) }\end{array}$ & $-0.6 \pm 1.58$ & $-0.74 \pm 1.92$ & $-0.46 \pm 1.57$ & $-0.58 \pm 1.86$ \\
\hline
\end{tabular}

Mild deficiency: 20-29.9 ng/mL, Medium deficiency: 10-19.9 ng/mL, Severe deficiency: $<10 \mathrm{ng} / \mathrm{mL}$ Normal: $30-120 \mathrm{ng} / \mathrm{mL}$

SD: Standard deviation, DEXA: Dual energy X-ray absorptiometry 
vitamin D levels, a statistically significant change was observed in severe deficiency patients $(p=0.001,0.001,0.0027,0.0003$ respectively) and this was shown in Figure 1 . BMD of patients with severe vitamin $D$ deficiency was very low. There was no statistically significant change in BMD when moderate and mild vitamin D deficiency was compared with normal vitamin D levels. Table 5 shows the comparison between the ferritin levels and BMD. When the patients' ferritin values and DEXA scores were compared with high ferritin values and low and normal ferritin values, femur T-score, lomber T-score, femur Z-score, and lomber Z-score were significantly lower in those with high ferritin values ( $p=0.0005,0.0002,<0.0001,0.0002$ respectively). In patients with a high level of ferritin, vitamin $D$ levels decrease but this is not statistically significant $(p=0.436)$.

\section{Discussion}

Previous studies reported that decreasing vertebral and femoral $\mathrm{BMD}$ are a major health problem in patients with thalassemia and sickle cell and more than 2/3 of these patients are affected $(8,9)$. Nakamura et al. (10), Vupputuri et al. (11), Pirinççioğlu et al. (12) and Frisk et al. (13) reported that the prevalence of osteoporosis was $40-62 \%$ in well-managed thalassemia major; our study is consistent with these studies and we found that more than $65 \%$ of the patients with thalassemia major who underwent regular transfusion and chelation treatment had osteopenia and osteoporosis. In addition, more than half of the patients with thalassemia intermedia were affected by

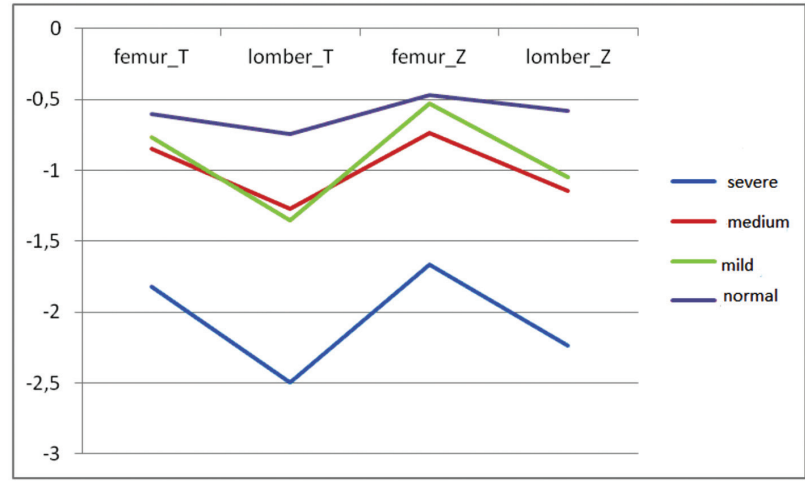

Figure 1. Association between vitamin D deficiency and bone mineral densitometry

Table 5. Comparison between ferritin levels and bone mineral densitometry of all patients

\begin{tabular}{|c|c|c|c|c|c|c|c|c|}
\hline Ferritin & $\begin{array}{l}\text { Femoral } \\
\text { T-score } \\
\text { mean } \pm \text { SD }\end{array}$ & $\mathbf{p}$ & $\begin{array}{l}\text { Lumbar } \\
\text { T-score } \\
\text { mean } \pm \text { SD }\end{array}$ & $\mathbf{p}$ & $\begin{array}{l}\text { Femoral } \\
\text { Z-score } \\
\text { mean } \pm \text { SD }\end{array}$ & $p$ & $\begin{array}{l}\text { Lumbar } \\
\text { Z-score } \\
\text { mean } \pm \text { SD }\end{array}$ & $\mathbf{p}$ \\
\hline $\begin{array}{l}\text { Normal } \\
\text { and low } \\
(n=24)\end{array}$ & $-0.16 \pm 2.13$ & 0.0005 & $-0.32 \pm 2.77$ & 0.0002 & $-0.04 \pm 2.19$ & $<0.0001$ & $-0.14 \pm 2.78$ & 0.0002 \\
\hline $\begin{array}{l}\text { High } \\
(n=78)\end{array}$ & $-1.41 \pm 1.24$ & - & $-1.99 \pm 1.44$ & - & $-1.26 \pm 1.31$ & - & $-1.79 \pm 1.46$ & - \\
\hline
\end{tabular}

osteopenia and osteoporosis. Osteopenia and osteoporosis defined by BMD are reported to be common in patients with sickle cell (53\%-86\%) (14). In our study, approximately $60 \%$ of the patients with sickle cell had osteopenia and osteoporosis.

In studies about the patients with thalassemia major, no significant association was found between vitamin $D$ levels and BMD and there is insufficient data on this issue in patients with sickle cell $(15,16)$. In this study, we found that vitamin D deficiency was quite common in our 3 patient groups and severe vitamin D deficiency and high ferritin levels were significantly associated with low BMD. But mild and moderate vitamin D deficiency was not significantly associated with low BMD. We think that vitamin D plays a key role in bone metabolism disorders in patients with hemoglobinopathy and this should be clarified with further studies.

The lumbar vertebrae BMD values of the patients with thalassemia were significantly lower than the femoral BMD values, which was consistent with the literature. It was argued that this was caused by bone marrow expansion due to the ineffective erythropoiesis resulting in thinning of trabecular bones such as lumbar vertebra more than the cortical bone (17). However, there was no statistically significant difference between femur and lumbar vertebrae BMD in patients with sickle cell anemia. In our study, 95\% of the patients had a high ferritin level, while there was a significant association between the ferritin levels and femoral and lumbar BMD values. Ferritin levels, and the BMD were negatively correlated. There are studies in the literature reporting that there is no correlation between the serum ferritin level and BMD (18-20) while contrary to these findings, there are other studies reporting a negative relationship between the serum ferritin level and BMD (21-23). Napoli et al. (24) found that there was a negative correlation between vitamin D level, age and serum ferritin level. They made a comparison between the patients with thalassemia with low vitamin $D$ levels and those with normal vitamin D levels and showed that patients with low vitamin D levels had higher serum ferritin and parathormon levels. Bisbocci et al. (25) found a significant reduction in the vitamin $D$ level in parallel to the elevated ferritin. In our study, we found a negative correlation between high ferritin level and vitamin D but it was not statistically significant. In patients with sickle cell, bone loss is attributed partly to bone marrow hyperplasia and inflammation secondary to chronic anemia or bone marrow ischemia. However, recent 
studies argue that children and adults usually have undetected severe vitamin D deficiency $(26,27)$. Therefore, our study will shed a guiding light in this field. Our findings show that vitamin $\mathrm{D}$ deficiency is very common in this group and affect $84.8 \%$ of the patients with sickle cell. Moreover, four studies found very low vitamin D levels in adults with sickle cell disease and only one of these studies was a controlled study and demonstrated that the serum concentrations of vitamin D was significantly lower in adult patients with sickle cell disease than in the control group $(12.6 \pm 8.7$ vs $36 \pm 3.4 \mathrm{ng} / \mathrm{mL}$ ) in Saudi Arabia (28). Deep vitamin $\mathrm{D}$ deficiency was also demonstrated in children with sickle cell disease. In a controlled study, Afro-American children with sickle cell disease in the USA had higher rates of vitamin D deficiency than the healthy Afro-American children living in the same geographical region. Malnutrition associated with low socioeconomic status could not explain the prevalence of vitamin D deficiency in these children. They demonstrated the evidence that vitamin $D$ deficiency could be a unique complication of sickle cell disease (29). Serum concentrations of vitamin D reflect the total vitamin D reservoir depending on exposure to sunlight (nearly $90 \%$ of vitamin D), diet and conversion to vitamin D from the fat storages in the liver (30). Very low concentrations of vitamin $D$ that is common in patients with sickle cell may be associated with a few mechanisms: low synthesis on the skin (given that vitamin D was found to be low in patients with sickle cell disease compared to the healthy controls with the same skin phenotype in some studies, this is not associated only with dark skin pigmentation), decreased absorption in the intestines and impaired fat tissue metabolism. Accumulation of bilirubin on the skin due to chronic hemolysis may possibly decrease the synthesis of vitamin $D$ from the ultraviolet $B$ rays of the sun. Vitamin $D$ deficiency in patients with sickle cell may also be associated with the malabsorption of this fat-soluble vitamin as also demonstrated in chronic cholestasis patients (31). In fact, black-pigmented biliary calculi caused by increased bilirubin expression and leading to low-grade biliary canal obstruction are common in these patients despite cholecystectomy (32).

Recent studies have shown that vitamin D deficiency is present in the majority of the patients with thalassemia and many factors have been suggested to explain the low serum vitamin $D$ levels in this patient group. Potential reasons are; intestinal malabsorption of vitamin $D$, impaired synthesis of vitamin $D$ by the skin because of jaundice and impaired 25 hydroxylation of vitamin $D$ due to decreased enzyme function because of parenchymal iron deposition in liver $(33,34)$.

In a study, although some patients were on treatment with oral vitamin $\mathrm{D}$ and calcium supplements at the time of measurement, only $12.4 \%$ of thalassemia major patients had normal vitamin D levels (35).

In our study, the patients who were using vitamin D or calcium supplements were excluded and only $10 \%$ of patients with thalassemia major and $25 \%$ of patients with thalassemia intermedia had normal vitamin D levels.

\section{Study Limitations}

The limitation of our study was the fact that our study was single-centered and the number of patients was not distributed homogenously between the groups. The other limitation was that vitamin $D$ and ferritin levels could not be compared with BMD in the subgroups due to the limited number of patients. However, contrary to many studies in the literature, the significant association of severe vitamin $D$ deficiency with BMD increases the importance of our study.

\section{Conclusion}

Severe deficiency of vitamin D and high ferritin levels may be associated with a decrease in BMD in patients with thalassemia major, intermedia and sickle cell. These patients should be screened through bone densitometry at an early age, and their bone parameters should be investigated. The efforts to provide appropriate vitamin D replacement and restore the ferritin levels to the normal range may be effective in reducing the morbidity associated with osteoporosis.

\section{Ethics}

Ethics Committee Approval: The study was approved by the Çukurova University Faculty of Medicine of Local Ethics Committee (decision no: 2014/27). All procedures performed in this study were in accordance with the ethical standards of the institutional research committee and with the 1964 Helsinki declaration and its later amendments.

Informed Consent: Consent form was filled out by all participants.

Peer-review: Externally peer-reviewed.

\section{Authorship Contributions}

Surgical and Medical Practices: M.B., I.F.B., Concept: M.B., I.F.B., Design: M.B., Data Collection or Processing: M.B., I.F.B., Analysis or Interpretation: M.B., Literature Search: M.B., Writing: M.B.

Conflict of Interest: The authors declared no conflict of interest. Financial Disclosure: The authors declared that this study received no financial support.

\section{References}

1. Haidar R, Musallam KM, Taher AT. Bone disease and skeletal complications in patients with $\beta$ thalassemia major. Bone 2011:48:425-32.

2. Tyler PA, Madani G, Chaudhuri R, Wilson LF, Dick EA. Theradiological appearances of thalassaemia. Clin Radiol 2006;61:40-52.

3. Dundar U, Kupesiz A, Ozdem S, Gilgil E, Tuncer T, Yesilipek A, et al. Bone metabolism and mineral density in patients with betathalassemia major. Saudi Med J 2007;28:1425-9.

4. Gaudio A, Morabito N, Xourafa A, Macrì I, Meo A, Morgante S, et al. Bisphosphonates in the treatment of thalassemia-associated osteoporosis. J Endocrinol Invest 2008;31:181-4.

5. Vogiatzi MG, Autio KA, Schneider R, Giardina PJ. Low bone mass in prepubertal children with thalassemia major: insights in to the pathogenesis of low bone mass in thalassemia. J Pediatr Endocrinol Metab 2004;17:1415-21.

6. Lorincz C, Manske SL, Zernicke R. Bone health: part 1, nutrition. Sports Health 2009;1:253-60. 
7. Balogh E, Paragh G, Jeney V. Influence of Iron on Bone Homeostasis. Pharmaceuticals (Basel) 2018;11.

8. Dede AD, Trovas G, Chronopoulos E, Triantafyllopoulos IK, Dontas I, Papaioannou N, et al. Thalassemia-associated osteoporosis: asystematic review on treatmentandbrief overview of the disease. Osteoporos Int 2016:27:3409-25

9. Hamdy M, Salama N, Maher G, Elrefaee A. Vitamin D and Nonskeletal Complications among Egyptian Sickle Cell Disease Patients. Adv Hematol 2018;2018:3867283.

10. Nakamura K, Ueno K, Nishiwaki T, Okuda Y, Saito T, Tsuchiya Y, et al. Nutrition, mild hyperparathyroidism, and bone mineral density in youngJapanesewomen. Am J Clin Nutr 2005:82:1127-33.

11. Vupputuri MR, Goswami R, Gupta N, Ray D, Tandon N, Kumar N. Prevalence and functional significance of 25-hydroxyvitamin D deficiency and vitamin $D$ receptorgene polymorphisms in Asian Indians. Am J Clin Nutr 2006:83:1411-9

12. Pirinççioğlu AG, Akpolat $V$, Köksal $O$, Haspolat K, Söker $M$ Bone mineral density in children with beta-thalassemia major in Diyarbakir. Bone 2011;49:819-23.

13. Frisk $P$, Arvidson J, Ljunggren $O$, Gustafsson J. Decreased bone mineral density in young adults treated with SCT in childhood: the role of 25-hydroxyvitamin D. Bone Marrow Transplant 2012;47:657-62.

14. Miller RG, Segal JB, Ashar BH, Leung S, Ahmed S, Siddique S, et al. High prevalence and correlates of low bone mineral density in young adults with sickle cell disease. Am J Hematol 2006;81:236 41.

15. Bielinski BK, Darbyshire P, Mathers L, Boivin CM, Shaw NJ. Bone density in the Asian thalassaemic population: a cross-sectiona review. Acta Paediatr 2001:90:1262-6.

16. Wonke B. Bone disease in beta-thalassaemia major. $\mathrm{Br} J$ Haematol 1998;103:897-901.

17. Jensen CE, Tuck SM, Agnew JE, Koneru S, Morris RW, Yardumian A, et al. High incidence of osteoporosis in thalassaemia major. J Pediatr Endocrinol Metab 1998;11 Suppl3:975-7.

18. Pollak RD, Rachmilewitz E, Blumenfeld A, Idelson M, Goldfarb AW. Bone mineral metabolism in adults withb-thalassaemia major and intermedia. Br J Haematol 2000;111:902-7.

19. Dandona P, Menon RK, Houlder S, Thomas M, Hoffbrand AV, Flynn DM. Serum 1,25 dihydroxyvitamin D andosteocalcinconcentrations in thalassaemia major. Arch Dis Child 1987:62:474-7.

20. Inati A, Noureldine MA, Mansour A, Abbas HA Endocrineand bone complications in $\beta$ - thalassemia intermedia: current understanding and treatment. Biomed Res Int 2015;2015:813098

21. Sadat-Ali M, Sultan O, Al-Turki H, Alelq A. Does high serum iron level induce low bone mass in sickle cell anemia? Biometals 2011;24:1922.
22. Eren E, Yilmaz N. Biochemical markers of bone turnover and bone mineral density in patients with beta-thalassaemia major. Int J Clin Pract 2005;59:46-51.

23. Mahachoklertwattana $P$, Chuansumrit A, Sirisriro $R$, Choubtum L, Sriphrapradang A, Rajatanavin R. Bone mineral density, biochemical and hormonal profiles in suboptimally treated children and adolescents with beta-thalassaemia disease. Clin Endocrinol (Oxf) 2003;58:273-9.

24. Napoli N, Carmina E, Bucchieri S, Sferrazza C, Rini GB, DiFede G. Low serum levels of 25-hydroxy vitamin $D$ in adults affected by thalassemia major or intermedia. Bone 2006;38:888-92.

25. Bisbocci D, Livorno P, Modina P, Gambino M, Damiano P, Cantoni $\mathrm{R}$, et al. [Osteodystrophy in thalassemia major]. Ann Ital Med Int 1993;8:224-6.

26. Adewoye $\mathrm{AH}$, Chen TC, Ma Q, McMahon L, Mathieu J, Malabanan $A$, et al. Sickle cell bone disease: response to vitamin $D$ and calcium. Am J Hematol 2008;83:271-4.

27. Soe HH, Abas AB, Than NN, Ni H, Singh J, Said AR, et al. Vitamin $\mathrm{D}$ supplementation for sickle cell disease. Cochrane Database Syst Rev 2017:1:CD010858.

28. Sadat-Ali M, Al-Elq A, Al-Turki H, Sultan O, Al-Ali A, AlMulhim F. Vitamin D levelamongpatients with sickle cell anemia and its influence on bone mass. Am J Hematol 2011;86:506-7.

29. Rovner AJ, Stallings VA, Kawchak DA, Schall JI, Ohene-Frempong $\mathrm{K}$, Zemel BS. High risk of vitamin D deficiency in children with sickle cell disease. J Am Diet Assoc 2008;108:1512-6.

30. Rosen CJ. Clinicalpractice. Vitamin D insufficiency. N Engl J Med 2011;364:248-54

31. Glass LM, Su GL. Metabolic Bone Disease in Primary Biliary Cirrhosis. Gastroenterol Clin North Am 2016;45:333-43.

32. Ebert EC, Nagar M, Hagspiel KD. Gastrointestinal and hepatic complications of sickle cell disease. Clin Gastroenterol Hepatol 2010;8:483-9; quiz e70.

33. Soliman A, Adel A, Wagdy M, Al Ali M, El Mulla N. Calcium homeostasis in 40 adolescents with b-thalassemia major: A case-control study of the effects of intramuscular injection of a megadose of cholecalciferol. Pediatr Endocrinol Rev 2008;6(Suppl 1):149-154

34. Singh K, Kumar R, Shukla A, Phadke SR, Agarwal S. Status of 25-hydroxyvitamin $D$ deficiency and effect of vitamin $D$ receptor gene polymorphisms on bone mineral density in thalassemia patients of North India. Hematology 2012;17:291-6.

35. Tzoulis $P$, Ang $A L$, Shah FT, Berovic $M$, Prescott $E$, Jones $R$, et al. Prevalence of low bone massand vitamin $D$ deficiency in $\beta$-thalassemia major. Hemoglobin 2014;38:173-8. 